
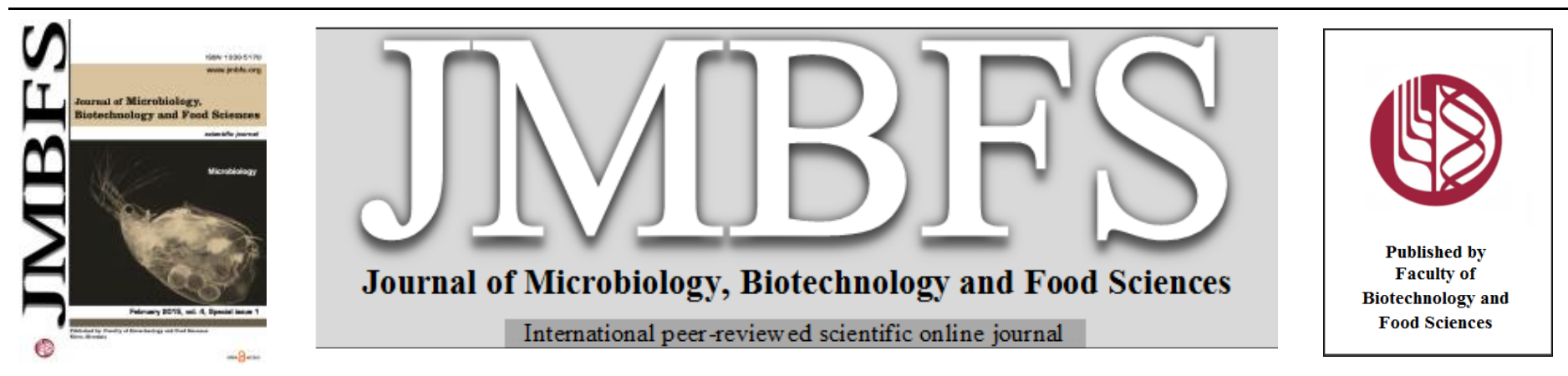

\title{
LIME PRETREATMENT OPTIMIZATION OF WHEAT STRAW TO IMPROVE ETHANOL PRODUCTION BY SACCHAROMYCES CEREVISIAE AND ITS VALIDATION
}

\author{
Miroslav Ondrejovič*, Veronika Dudášová, Daniela Chmelová
}

Address(es): RNDr. Miroslav Ondrejovič, PhD.,

University of Ss. Cyril and Methodius, Faculty of Natural Sciences, Department of Biotechnology, Nám. J. Herdu 2, 91701 Trnava, Slovak Republic.

*Corresponding author: miroslav.ondrejovic@ucm.sk

doi: $10.15414 / j m b f s .2015 .4 . s p e c i a l 1.45-47$

\section{ARTICLE INFO}

Received 6. 11. 2014

Revised 9. 12. 2014

Accepted 11. 12. 2014

Published 2. 2. 2015

Regular article

open $\partial$ access

\begin{abstract}
The aim of this study was to optimize of independent variables as temperature, time and reaction ratio to output parameter of simultaneous enzyme saccharification and fermentation by Saccharomyces cerevisiae of pretreated wheat straw as model substrate via RSM (response surface methodology) approach. As dependent variable, it was chosen ethanol yields characterizing effectivity of process. The optimal conditions were approximately temperature $100{ }^{\circ} \mathrm{C}$, time 1 hour and reaction ratio $26 \mathrm{~mL}$ to $1 \mathrm{~g}$ of treated wheat straw with ethanol yields $141.9 \mathrm{mg} \cdot \mathrm{g}^{-1}$. After calculating the optimal values, the validation analyze was carried out and it was found out that the predicted and experimentally verified dependent variable was in agreement with the optimal parameters $(\sim 95 \%)$. Proposed model was tested for three lignocellulosic materials (winter wheat straw, alfalfa hay and maize straw) as wheat straw used as model substrate and it was confirmed the possibility of its use for other agricultural residues with similar content of lignocellulose.
\end{abstract}

Keywords: Response surface methodology, lime, wheat straw, Saccharomyces cerevisiae

\section{INTRODUCTION}

Wheat straw is fast-growing and abundant agricultural by-product used as bedding material. This material belongs to agricultural residues which have relative low levels of lignin in comparison with hardwood or softwood. Wheat

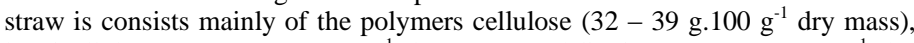
hemicelluloses $\left(29-38\right.$ g.100 $\mathrm{g}^{-1}$ dry mass $)$ and lignin $\left(16-17 \mathrm{~g} .100 \mathrm{~g}^{-1}\right.$ dry mass), but significant amounts of inorganic material (ash) and extractives are present as well (Demirbas, 2005).

The pretreatment of lignocellulosic materials is one of the most challenging steps in the whole process. The aim of plant material pretreatment is to increase the availability of lignocellulose for enzymatic cleavage of hydrolases (cellulases and hemicellulases) (Szczodrak and Fiedurek, 1996). Plant material can be pretreated chemical, physical or biological methods. Whereas the physical methods caused mainly increase the specific surface, chemical methods is used for disruption of chemical bonds which linked polymers of lignocelluloses (Szczodrak and Fiedurek, 1996; Gable and Zachci, 2007; Olofsson et al., 2008). Lime pretreatment is considered to be one of the most promising methods for pretreatment of lignocellulosic materials with low lignin content (Mosier et al., 2005; Carvalheiro et al., 2008; Wang, 2009, Ondrejovič et al., 2014). This method is relative cheap, compatible with other oxidants, exhibits good carbohydrate preservation and is easy to recover (Liang et al., 2013).

The aim of this study was to optimize the temperature, time and reaction ratio (calcium hydroxide to wheat straw) for wheat straw pretreatment by lime in account to maximization of ethanol yields obtained by simultaneous saccharification and fermentation with Saccharomyces cerevisiae using response surface methodology (RSM). Proposed method was subsequently validated on three lignocellulosic materials (winter wheat straw, alfalfa hay and maize straw) which have a similar composition as wheat straw used as model substrate.

\section{MATERIAL AND METHODS}

\section{Material}

Post-grain harvested wheat straw (Triticum aestivum), winter wheat straw (Triticum aestivum), alfalfa hay (Medicago sativa) and maize straw (Zea mays) were sourced from the plains in the area of Male Karpaty, Slovakia. These materials were dried at $40{ }^{\circ} \mathrm{C}$ for 72 hours. Thereafter, they were ground in hammer mill and passed through a $0.5 \mathrm{~mm}$ screen. Extractives compounds were removed by Soxhlet extraction for 6 hour with methanol, dried at laboratory temperature and stored in glass flasks.

\section{Microorganism and inoculum}

Saccharomyces cerevisiae CCY-11-3 was maintained on agar plates at $4{ }^{\circ} \mathrm{C}$ to be used in the experiments. For inoculum preparation, cells were transferred to 100 $\mathrm{ml}$ Erlenmeyer flasks contained $50 \mathrm{~mL}$ of inoculum medium composed by 10 g.L $\mathrm{L}^{-1}$ glucose, 5 g.L. $\mathrm{L}^{-1}$ ammonium sulfate; 3 g.L. $\mathrm{L}^{-1}$ yeast extract; 2 g.L. $\mathrm{L}^{-1} \mathrm{KH}_{2} \mathrm{PO}_{4}$; 1 g.L $\mathrm{L}^{-1} \mathrm{MgSO}_{4} .7 \quad \mathrm{H}_{2} \mathrm{O} ; 0.1$ g.L. $\mathrm{L}^{-1} \mathrm{CaCl}_{2} .2 \mathrm{H}_{2} \mathrm{O}$ and 0.1 g.L. $\mathrm{L}^{-1} \mathrm{NaCl}$, sterilized at $121{ }^{\circ} \mathrm{C}$ for 20 minutes in an autoclave. Inoculum medium was inoculated with $S$ cerevisiae (1 microbiological loop to $10 \mathrm{ml}$ medium). The flasks were incubated aerobically on a rotatory shaker $(150 \mathrm{RPM})$ at $30{ }^{\circ} \mathrm{C}$ for 24 hours and the inoculum was transferred to the basal cultivation medium in ratio $1: 10(\mathrm{v} / \mathrm{v})$.

\section{Experimental design for the response surface methodology (RSM)}

The RSM used a three-factor and central composite design in three blocks consisting of 17 experimental runs at the centre point. The design variables were the temperature $\left(50,60,75,90,100{ }^{\circ} \mathrm{C} ; \mathrm{X}_{1}\right)$, the time $\left(1,1.4,2,2.6,3\right.$ hours; $\left.\mathrm{X}_{2}\right)$ and the reaction ratio $(10,14,20,26,30 \mathrm{~mL}$ of $1 \%(\mathrm{w} / \mathrm{v})$ suspension of calcium hydroxide to $1 \mathrm{~g}$ of dry wheat straw; $\mathrm{X}_{3}$ ) (Table 1 ).

The experimental design of described independent variables in their original and coded form is shown in Table 2. The dependent variable was ethanol yields obtained by simultaneous saccharification and fermentation by $S$. cerevisiae of pretreated wheat straw. Experimental data were fitted to the following secondorder polynomial model (Eq. 1) and regression coefficients were obtained.

$$
Y=b_{0}+\sum_{i=1}^{k} b_{i} X_{i}+\sum_{i=1}^{k} b_{i i} X_{i}^{2}+\sum_{\substack{i=1 \\ i<j}}^{k-1} \sum_{j=2} b_{i j} X_{i} X_{j}
$$

where $X_{1}, X_{2}, \ldots, X_{k}$ are the independent variables affected the response (dependent variable; $Y), b_{0}, b_{i}(i=1,2, \ldots, k), b_{i i}(i=1,2, \ldots, k)$ and $b_{i j}(i=1,2, \ldots k$ $-1 ; j=2,3, \ldots, k)$ are regression coefficients for intercept, linear, quadratic, and interaction terms, respectively, $\mathrm{k}$ is the number of variables. 
Table 1 Independent variables and their coded and actual values used for optimization

\begin{tabular}{lccccccc}
\hline \hline \multirow{2}{*}{ Factors } & \multicolumn{7}{c}{ Coded levels } \\
& -1.682 & -1 & 0 & 1 & 1.682 & Step & Mean \\
\hline \hline Temperature $\left[{ }^{\circ} \mathrm{C}\right]$ & 50 & 60 & 75 & 90 & 100 & 15 & 75 \\
\hline Time $[$ hour] & 1 & 1.4 & 2 & 2.6 & 3 & 0.6 & 2 \\
\hline Reaction ratio $\left[\mathrm{mL} \cdot \mathrm{g}^{-1}\right]$ & 10 & 14 & 20 & 26 & 30 & 6 & 20 \\
\hline \hline
\end{tabular}

The optimum conditions were calculated using Statgraphic 5.1 (Statpoin technologies, INC., Warrenton, Virginia, USA). The verification of the validity and adequacy of the predictive extraction model was carried out in these optimum conditions of temperature, time and reaction ratio. Three experimental replicates were performed at the optimized conditions and the experimental and predicted values were compared.

\section{Analyses of the response variable}

\section{Simultaneous saccharification and fermentation}

Solid treated or untreated plant material (wheat straw, winter wheat straw, alfalfa hay, maize straw), $(0.5 \mathrm{~g})$ was resuspended in solution $(10 \mathrm{~mL})$ of basal cultivation medium $\left(5\right.$ g. L $\mathrm{L}^{-1}\left(\mathrm{NH}_{4}\right)_{2} \mathrm{SO}_{4} ; 5$ g. L ${ }^{-1}$ yeast extract; 4 g. L ${ }^{-1} \mathrm{KH}_{2} \mathrm{PO}_{4}$ 0.5 g. $\mathrm{L}^{-1} \mathrm{CaCl}_{2} .2 \mathrm{H}_{2} \mathrm{O} ; 0.5 \mathrm{~g}$. $\left.\mathrm{L}^{-1} \mathrm{NaCl}\right)$. Prepared medium was sterilized at 121 ${ }^{\circ} \mathrm{C}$ during 20 minutes. After cooling, medium was inoculated by suspension S. cerevisiae CCY-11- with optical density 2.0 MFU (McFarland units) in ratio $1: 10(\mathrm{v} / \mathrm{v})$. After inoculation, medium was enriched by technical enzyme solution Viscozyme L. in ratio $1: 5(\mathrm{v} / \mathrm{v})$. Fermentation carried out at $30{ }^{\circ} \mathrm{C}$ during 7 days with shaking (150 RPM). Ethanol yields were determined by gas chromatography.

\section{Ethanol yields}

The ethanol yields occurred by simultaneous saccharification and fermentation of plant material by $S$. cerevisiae was determined by head space gas chromatography with flame ionization detector (HS-GC-FID) (Perkin Elmer AutoSystem XL). $5 \mathrm{~mL}$ of fermentation medium was pipetted into headspace vial with volume $20 \mathrm{~mL}$. The parameter of head space autosampler was: thermostat temperature $60^{\circ} \mathrm{C}$, thermostat time 4 minutes, pressurization time 50 seconds ( 2.75 bar), injection time 9 seconds and 30 seconds of ventilation. Separation of sample components was ran in capillary column Super-Q PLOT $(30 \mathrm{~m}$ x 0.53 $\mathrm{mm}$ ) using nitrogen at 2.6 bar as carrier gas at isocratic separation mode of oven temperature $\left(105^{\circ} \mathrm{C}\right)$. Injector temperature was $200{ }^{\circ} \mathrm{C}$ and detector temperature was $250^{\circ} \mathrm{C}$

\section{Reducing saccharide yields}

The reducing saccharide yields by enzymatic hydrolysis of plant material was determined by 3,5-dinitrosalicylic acid (DNS) method (Miller, 1959). $0.8 \mathrm{~mL}$ of DNS reagent was added to $0.1 \mathrm{~mL}$ of hydrolysate. Reaction mixture was incubated in boiling water bath for 5 minutes. The mixture was cooled down to room temperature and $8 \mathrm{~mL}$ of distilled water was added. The absorbance of the reaction mixture $(200 \mu \mathrm{L})$ was measured at $540 \mathrm{~nm}$ using a microplate reader (BioTek EL 800, Fisher, GE). Reducing saccharide yields were calculated by Equation 2:

Reducing saccharide yields $=\frac{\mathrm{c} . \mathrm{V}}{\mathrm{m}}$,

were $\mathrm{c}$ is concentration of reducing saccharides determined by DNS method, V is volume of enzymatic hydrolysate and $\mathrm{m}$ is mass of hydrolysed plant material.

\section{RESULTS AND DISCUSSION}

\section{Selection of experimental ranges}

The ether and ester bonds in lignocellulosic material are cleaved in the presence of alkaline solutions to release cellulose fibers and hemicelluloses, which are thereby more accessible for enzyme hydrolysis (Hammel and Cullen, 2008) While ether bonds are characteristic of a wood material, ester bonds are mainly in grasses such as wheat straw (Buranov and Mazza, 2008). For this reason, the application of calcium hydroxide pretreatment seems more suitable for grass pretreatment.

Pretreatment conditions (temperature, time and reaction ratio) significantly influence accessibility of lignocellulosic material for hydrolases (cellulases and hemicellulases) and related to ethanol production by S. cerevisiae. Based upon prior results from applying lime to wheat straw, the following ranges were tested $50-100{ }^{\circ} \mathrm{C}, 1-3$ hours reaction time and reaction ratio $5-20 \mathrm{ml}$ to $1 \mathrm{~g}$ of dry wheat straw (Ondrejovič $\boldsymbol{e}$ t al., 2014). Whereas the appropriate fermentation utilization of lignocellulose is required sufficient enzyme hydrolysis, we selected the optimization ranges on the base optimization ranges for enzymatic hydrolysis of pretreated wheat straw which was published in our previously work (Ondrejovič et al., 2014)

\section{Optimization of lime pretreatment by RSM}

Response surface methodology (RSM) is a useful statistical technique for optimization of complex reaction process. This method was used in many studies which were focused on optimization of natural compounds extractions (LiyanaPathirana and Shahidi 2005; Silva et al. 2007; Mikulajová et al. 2007). The effects of selected parameters (temperature, time and reaction ratio) of lime pretreatment on ethanol yields were optimized through RSM approach. Results of ethanol yields occurred by simultaneous saccharification and fermentation of pretreated plant material as dependent variable for all runs are reported in Table 2.

Table 2 Experimental data for ethanol yields occurred by simultaneous saccharification and fermentation of pretreated wheat straw by $1 \%(w / v)$ suspension of calcium hydroxide at described conditions

\begin{tabular}{ccccc}
\hline \hline No. & $\begin{array}{c}\text { Temperature } \\
{\left[{ }^{\circ} \mathbf{C}\right]}\end{array}$ & $\begin{array}{c}\text { Time } \\
{[\text { hour }]}\end{array}$ & Reaction ratio $\left[\mathbf{m L . g}{ }^{-1}\right]$ & $\begin{array}{c}\text { Ethanol yields } \\
{\left[\mathbf{m g . g}^{-1}\right]}\end{array}$ \\
\hline \hline 1 & $90(1)$ & $2.6(1)$ & $14(-1)$ & 97.7 \\
\hline 2 & $60(-1)$ & $2.6(1)$ & $26(1)$ & 95.8 \\
\hline 3 & $90(1)$ & $1.4(-1)$ & $26(1)$ & 118.7 \\
\hline 4 & $60(-1)$ & $1.4(-1)$ & $14(-1)$ & 92.1 \\
\hline 5 & $75(0)$ & $2(0)$ & $20(0)$ & 101.1 \\
\hline 6 & $90(1)$ & $2.6(1)$ & $26(1)$ & 95.8 \\
\hline 7 & $90(1)$ & $1.4(-1)$ & $14(-1)$ & 118.9 \\
\hline 8 & $60(-1)$ & $2.6(1)$ & $14(-1)$ & 116.7 \\
\hline 9 & $75(0)$ & $2(0)$ & $20(0)$ & 118 \\
\hline 10 & $60(-1)$ & $1.4(-1)$ & $26(1)$ & 132.7 \\
\hline 11 & $75(0)$ & $3(1.682)$ & $20(0)$ & 94.9 \\
\hline 12 & $75(0)$ & $2(0)$ & $30(1.682)$ & 102.2 \\
\hline 13 & $75(0)$ & $2(0)$ & $10(-1.682)$ & 86.9 \\
\hline 14 & $75(0)$ & $1(-1.682)$ & $20(0)$ & 101.4 \\
\hline 15 & $75(0)$ & $2(0)$ & $20(0)$ & 120.2 \\
\hline 16 & $50(-1.682)$ & $2(0)$ & $20(0)$ & 105.9 \\
\hline 17 & $100(1.682)$ & $2(0)$ & $20(0)$ & 119.9 \\
\hline \hline & & & & \\
\hline
\end{tabular}

\section{Analyses of the regression coefficients and the response surface}

The regression coefficients of the model for ethanol yields obtained by the multiple linear regression are reported in Table 3. Variables in their coded form (Table 2) permitted a direct interpretability of effects (linear, quadratic and interaction) of independent variables.

Table 3 Regression coefficients of second-order model for dependent variable

\begin{tabular}{|c|c|c|}
\hline Model parameters & & Regression coefficient \\
\hline Constant effect & & -141.63 \\
\hline Linear effect & $\begin{array}{c}\text { Temperature (A) } \\
\text { Time (B) } \\
\text { Reaction ratio }(\mathrm{C})\end{array}$ & $\begin{array}{c}0.484547 \\
109.319 \\
12.6837 \\
\end{array}$ \\
\hline Quadratic effect & $\begin{array}{l}\mathrm{A} \times \mathrm{A} \\
\mathrm{B} \times \mathrm{B} \\
\mathrm{C} \times \mathrm{C} \\
\end{array}$ & $\begin{array}{c}0.007283 \\
-0.4425 \\
-0.03042 \\
\end{array}$ \\
\hline Interactive effect & $\begin{array}{l}A \times B \\
A \times C \\
B \times C\end{array}$ & $\begin{array}{c}0.007283 \\
-0.4425 \\
\mathbf{- 2 . 1 9 3 0 6}\end{array}$ \\
\hline
\end{tabular}

Regression coefficients with a statistically significant at $\mathrm{p}<0.05$ are printed in bold

Figure 3 shows the response surface plot of the effects of temperature, time and reaction ratio on ethanol yields occurred by simultaneous saccharification and fermentation by $S$. cerevisiae determined using Eq. 1 . 

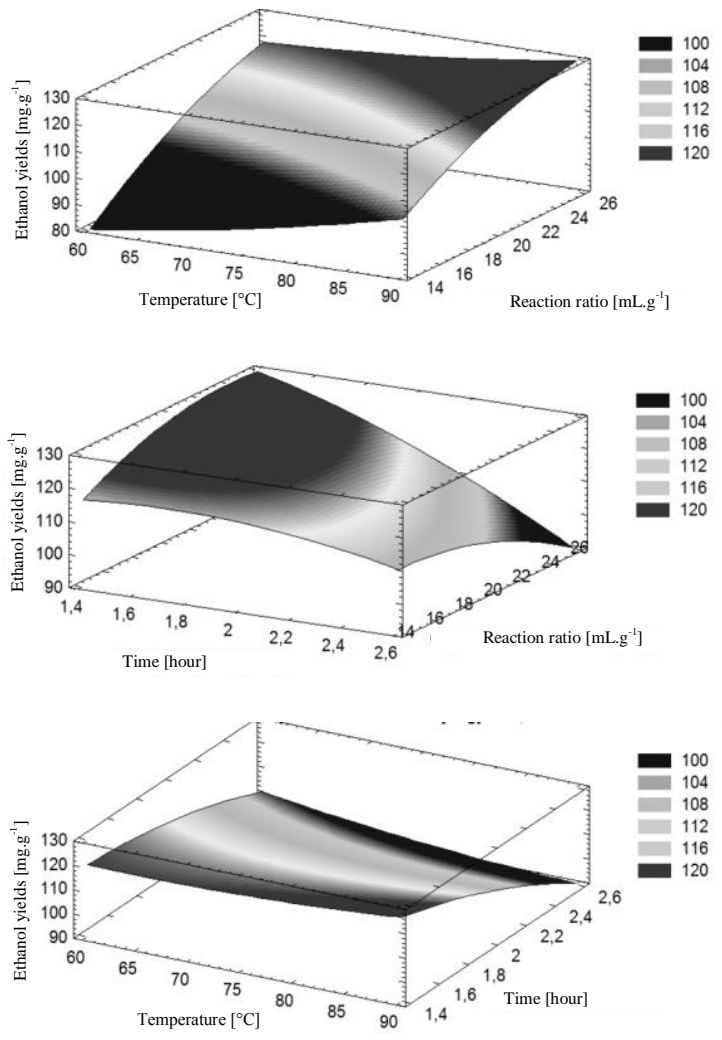

Figure 3 Response surface and contour plots for the effects of time, temperature and reaction ratio for ethanol yields occurred by simultaneous saccharification and fermentation of pretreated wheat straw by $1 \%(\mathrm{w} / \mathrm{v})$ suspension of calcium hydroxide

\section{Determination and experimental validation of the optimal conditions}

In order to verify the predictive capacity of the model, optimal conditions were determined using the simple method and the maximum desirability for ethanol yields, and they were used for a validation test of wheat straw pretreatment by lime (Table 4). The measured value lay within a 95\% mean confidence interval of the predicted values of dependent variable. These results confirm the predictability of the model for the wheat straw pretreatment by lime in the used experimental ranges.

Table 4 Comparison of predicted and experimental values for the response variable

\begin{tabular}{lc}
\hline \hline Parameters & Ethanol yields $\left[\mathrm{mg.g}^{-1}\right]$ \\
\hline \hline Temperature $\left[{ }^{\circ} \mathrm{C}\right]$ & 100 \\
Time $[$ hour $]$ & 0.99 \\
Reaction ratio $\left[\mathrm{mL} \cdot \mathrm{g}^{-1}\right]$ & 26.1 \\
\hline Predicted value & 135.8 \\
Experimental value & 141.9 \\
\hline
\end{tabular}

The proposed prediction model can be used to other plant materials with comparable composition. We verified the possibility of using the results for three waste plant material such as winter wheat straw, alfalfa hay and maize straw. These materials have similar polysaccharide and lignin content.

Table 5 Yields of reducing saccharides after enzymatic hydrolysis of selected pretreated lignocellulosic materials with $1 \%(\mathrm{w} / \mathrm{v})$ calcium hydroxide under optimal conditions from RSM

\begin{tabular}{lcccc}
\hline \hline & $\begin{array}{c}\text { Wheat } \\
\text { straw }\end{array}$ & $\begin{array}{c}\text { Winter wheat } \\
\text { straw }\end{array}$ & $\begin{array}{c}\text { Maize } \\
\text { straw }\end{array}$ & $\begin{array}{c}\text { Alfalfa } \\
\text { hay }\end{array}$ \\
\hline \hline $\begin{array}{l}\text { Reducing saccharide yields } \\
\text { [mg.g }^{-1} \text { plant material] }\end{array}$ & 432.0 & 395.5 & 369.3 & 366.5 \\
\hline Ethanol yields [mg.g ${ }^{-1}$ ] & 141.9 & 142.9 & 162.6 & 170.6 \\
\hline
\end{tabular}

Reducing saccharide yields were in range from $366.5-432.0 \mathrm{mg} \cdot \mathrm{g}^{-1}$ plant material and ethanol yields from 141.9 to $170.6 \mathrm{mg} \cdot \mathrm{g}^{-1}$. Reducing saccharide and ethanol yields after simultaneous saccharification and fermentation by $S$ cerevisiae were comparable for pretreated wheat and winter wheat straw with lime. Although reducing saccharide yields were lower for maize straw and alfalfa hay substrates, ethanol yields were higher in comparison with pretreated wheat straw. Highest ethanol yields $\left(170.6 \mathrm{mg} \cdot \mathrm{g}^{-1}\right)$ relative to the amount reducing saccharides released $\left(366.5 \mathrm{mg} . \mathrm{g}^{-1}\right.$ plant material) was observed after pretreated alfalfa hay fermentation by yeast $S$. cerevisiae.

\section{CONCLUSION}

The effects of temperature, time and reaction ratio on pretreatment of wheat straw with $1 \%(\mathrm{w} / \mathrm{v})$ calcium hydroxide have been investigated. The response surface methodology was successfully employed to optimize the lime pretreatment of wheat straw. The second-order polynomial model gave a satisfactory description of the experimental data. The optimal conditions for maximum ethanol yields occurred by enzyme hydrolysis of pretreated wheat straw were: temperature $100{ }^{\circ} \mathrm{C}$, time 0.99 hours and reaction ratio $26.1 \mathrm{~mL}$ to $\mathrm{g}$ of treated wheat straw. Proposed model can be used for other lignocellulosic materials with similar composition of lignocellulose as wheat straw.

Acknowledgments: This work was supported by the grant No. VEGA 2/0085/13.

\section{REFERENCES}

BURANOV, A.U., MAZZA, G. 2008. Lignin in straw of herbaceous crops. Industrial Crops and Products, 28(3), 237-259. http://dx.doi.org/10.1016/j.indcrop.2008.03.008

CARVALHEIRO, F., DURATE, L.C., GÍRIO, F.M. 2008. Hemicellulose biorefineries: a review on biomass pretreatments. Journal of Scientific and Industrial Research, 67(11), 849-864.

DEMIRBAS, A. 2005. Bioethanol from cellulosic materials: A renewable motor fuel from biomass. Energy Sources, 27(4), 327-337. http://dx.doi.org/10.1080/00908310390266643

GABLE, M., ZACHCI, G. 2007. Pretreatment of lignocellulosic materials for efficient bioethanol production. Advances in Biochemical Engineering Biotechnology, 108(1), 41-65. http://dx.doi.org/10.1007/10_2007_070

HAMMEL, K.E., CULLEN, D. 2008. Role of fungal peroxidases in biological ligninolysis. In Current Opinion in Plant Biology, roč. 11, 2008, č. 3, s. 349-355. http://dx.doi.org/10.1016/j.pbi.2008.02.003

LIANG, Y.G., ZHENG, Z., LUO, X.Z., SI, Y.B., CAO, D.J., NIE, E., CHENG, B. 2013. Lime pretreatment to improve methane production of smooth cordgrass (Spartina alterniflora). Chemical Engineering Journal, 217(1), 337-344. http://dx.doi.org/ 10.1016/j.cej.2012.11.135

LIYANA-PATHIRANA, C.M., SHAHIDI, F. 2005. Optimization of extraction of phenolic compounds from wheat using response surface methodology. Food Chemistry, 93(1), 47-56. http://dx.doi.org/10.1016/j.pbi.2008.02.003

MIKULAJOVÁ, A., TAKÁCSOVÁ, M., ALEXY, P., BRINDZOVÁ, L. 2007. Optimalizácia extrakcie fenolových zložiek z pohánky na základe výsledkov plánovaného experimentu. Chemické Listy, 101(7), 563-568.

MILLER, G.L. 1959. Use of dinitrosalicylic reagent for the determination of reducing sugar. Analytical Chemistry, 31(3), 426-428. http://dx.doi.org/10.1021/ac60147a030

MOSIER, N., WYMAN, C., DALE, B., ELANDER, R., LEE, Y.Y., HOLTZAPPLE, M.. LADISCH, M. 2005. Features of promising technologies for pretreatment of lignocellulosic biomass. Bioresource Technology, 96(6), 673686. http://dx.doi.org/ 10.1016/j.biortech.2004.06.025

OLOFSSON, K., MAGNUS, B., LIDÉN, G. 2008. A short review on SSF - An interesting process option for ethanol production from lignocellulosic feedstocks. Biotechnology for Biofuels, 1(1), 1-7. http://dx.doi.org/10.1186/1754-6834-1-7 ONDREJOVIČ, M., JANÍKOVÁ, V., CHMELOVÂ, D. 2014. Optimization of lime pretreatment for enzymatic saccharification of wheat straw. Journal of Microbiology, Biotechnology and Food Sciences, 3 (3), 138-141.

SILVA, E.M., ROGEZ, H., LARONDELLE, Y. 2007. Optimization of extraction of phenolics from Inga edulis leaves using response surface methodology. Separation and Purification Technology, 55(3), 381-387. http://dx.doi.org/10.1016/j.seppur.2007.01.008

SZCZODRAK, J., FIEDUREK, J. 1996. Technology for conversion of lignocellulosic biomass to ethanol. Biomass and Bioenergy, 10(5-6), 367-375. http://dx.doi.org/10.1016/0961-9534(95)00114-X

WANG, Z. 2009. Alkaline pretreatment of coastal bermudagrass for bioethanol production. Dissertation. North Carolina: Faculty of North Carolina State University, 2009. $116 \mathrm{p}$. 